\title{
Investigation of the Pile Aging Effect of a Fixed Offshore Platform Located in Persian Gulf using Nonlinear Soil-Pile Interactions
}

\author{
Ghafour Emamverdizadeh beyg ${ }^{1}$, Abdolrahim Taheri ${ }^{2 *}$ \\ ${ }^{1}$ Ghafour Emamverdizadeh beyg, Petroleum University of Technology; g.emamverdi@mnc.put.ac.ir \\ ${ }^{2}$ Assistant Professor of Offshore Structures Department, Petroleum University of Technology, \\ rahim.taheri@put.ac.ir
}

\section{ARTICLE INFO}

Article History:

Received: 27 May. 2017

Accepted: 21 Sep. 2017

\section{Keywords:}

Jacket Platform

SACS

Pushover Analysis

Aging Effect

Persian Gulf

\begin{abstract}
The study about the jacket platforms in the past has revealed that the most of the collapse failures occur due to the lack of strength of the pile foundation. However, when the jacket platforms which have been collapsed due to extreme condition were looked into, it was found that most of them had their foundations intact. These contrasting facts can be explained with the help of the phenomenon called "aging of piles". Aging effect of piles has been proven by experiments indicating gradual increase in pile capacity which is due to the thixotropic characteristics of clayey soils, leading to gradual improvement of soil clamping property. But due to lack of proper understanding and suitable techniques to incorporate them, these aging effects have been ignored during the pushover analysis. In this study, a simple technique of stepping up of the soil curves in order to accommodate the increase in capacity of pile foundation due to aging is utilized, and then the pushover analysis is performed using commercial software SACS. SPD19C (South Pars gas field Development, phase 19) is a new constructed jacket platform in Persian Gulf which is used as the case study in this paper. The platform is considered to be under the storm condition in $180^{\circ}$ direction which is the worst condition. This study shows that the incorporation of pile aging effect results in the improvement the piles performance and Reserve Strength Ratio (RSR) about 10 percent. This research also has provided a deeper knowledge into the behavior of aged offshore jacket platforms.
\end{abstract}

\section{Introduction}

Offshore jacket platforms are normally designed for around 25 years design life. During the service life of the platform, it may be required to take more provisions than its design capacity due to the change in environmental loading, modification in the use of the platform and work over demands. Due to the reliability assessments of the aged platforms, PCSB (Petronas Carigali Sdn Bhd) have found out that the factor of safety for pile foundation capacity is very low [1]. Such cases necessitate the evaluation the integrity of the structure. Nonlinear pushover analysis is the most common technique for the purpose of the investigating the pile aging [2].

Study about the reasons of the failure of the jacket platforms in the past, has shown that the failure of a platform happens mostly due to the foundation failure. But the actual case scenarios of platforms which were acted upon by extreme environmental condition like storm and hurricanes have shown that the foundation remained intact when the platform failed [3]. These contrasting facts can be explained with the help of the phenomenon called aging of piles. Aging effect of piles have been experimentally proven to improve the pile capacity with time, but due to lack of proper understanding and suitable techniques to incorporate them, these aging effects have been ignored during the relevant analyses such as pushover analysis [4]. This effect can be incorporated into the pushover analysis using a simple technique of stepping up of pile soil interaction curves to model the improvement in pile capacity.

The main objective of this study is to investigate the aging effect on the RSR (Reserve Strength Ratio) of the platform and also to provide a better understanding of the behavior of aged offshore jacket platforms.

\section{Aging Effect of Piles}

The capacity of piles is known to be changing with time. The pile capacity calculated from the past 
equation does not consider the effect of time on the pile capacity. After longtime there will be a good bond between the pile and the surrounding soil, hence this additional adhesion is not considered in the calculation of pile capacity. In this regard, some studies were performed to define the behavior of the axial capacity in clay soil with time [5]. Clarke (1993) and Bogard and Matlock (1990) conducted field measurements studies and concluded that the time required for driven piles to reach ultimate capacity in a cohesive soil can be relatively long, as much as 2_3 years [6], [7].

The gain in capacity of piles is known as setup. The gain in capacity form the end of driving of pile to the end of consolidation phase is known as short term effects. Short term effects are mainly due to equalization of excess pore water pressure built up during driving (also known as consolidation) [8]. The gain in capacity after end of consolidation is known as long term effect or aging effects and it can be the result of a combination of mechanisms such as [9]:

- Increase in the earth pressure against of the pile surface on the long term, due to creep of the soil structure.

- Long-term build-up of new diegetic bonds between soil particles, after the complete destruction of the soil the structure due to the severe displacement and disturbance resulting from the driving of the pile into the ground.

- Chemical bonding due to the interaction the steel pile surface and the soil minerals (cation exchange)

- Effects of sustained load on the piles, gradually causing a more stable the soil structure and increase strength.

- Effects of previous loading and unloading cycles of the piles which may have similar effects as sustained loading.

The most popular time effects for capacity of piles was presented by Skov and Denver (1988), which models aging as linear with respect to the log of time. They proposed a semi-logarithmic relationship to describe aging as [10][2]:

$$
Q_{t} /_{Q_{0}}=1+\Delta_{10}\left[\log \left(t / t_{0}\right)\right]
$$

$\mathrm{Q}_{\mathrm{t}}=$ Axial capacity at time $\mathrm{t}$ after consolidation,

$\mathrm{Q}_{\mathrm{o}}=$ Axial capacity at the reference time $\mathrm{t}_{\mathrm{o}}$,

$\Delta_{10}=$ Setup factor, a constant depending on soil type

$t_{\mathrm{o}}=$ the reference time at which $\mathrm{Q}_{\mathrm{o}}$ is measured

The average setup factors for offshore clayey soil conditions were found to be 0.215 for a reference time of 100 days [4]. This setup factor value has been used in Eq. (1) to find the ratio of the pile capacity after design life (25 years) to the pile capacity at the reference time (100 days) as 1.42 .
SACS is the commercial structural analysis software which is used in this study. In SACS, the pile soil modelling is done in a module known as PSI (pile structure Interaction). In PSI, the soil is defined in terms of soil curves namely side shear curve ( $\mathrm{t}-\mathrm{z})$, end bearing curve $(\mathrm{Q}-\mathrm{z})$ and lateral strength curve $(\mathrm{p}-\mathrm{y})$ [11].

The soil curves should be modified to accommodate the pile capacity improvement due to aging effect. $Q$ and $t$ are the factors in the Q-z and the $\mathrm{t}-\mathrm{z}$ curves that should be stepped up by a factor for the same axial displacement to modify the axial capacity of piles. In another words, $\mathrm{t}$ and $\mathrm{Q}$ values are identically and manually increased by the author in every axial displacement and 25-year bearing capacity is obtained via interpolation in order to improve $\mathrm{Q}_{0}$ to $\mathrm{Q}_{\mathrm{t}}$. $\mathrm{By}$ studying the variation of capacity of piles with the application of random $t$ factor and $\mathrm{Q}$ factors, it was observed that $\mathrm{t}$ factor has more influence on capacity improvement. Also the lateral capacity improvement due to aging effect is included by stepping up of the py curve.

Table-1 shows the actual and aged foundation capacities, the required and obtained capacity ratio of the SPD19C (South Pars gas field Development, phase 19) jacket platform in which $\mathrm{p} 1$ and $\mathrm{p} 2$ piles have the diameter of $152.4 \mathrm{~cm}$ and penetration depth of $88.47 \mathrm{~m}$ and $94.483 \mathrm{~m}$ respectively. The obtained capacity ratio is in close agreement with the required ratio. Since the SACS software has not any procedure to use the method of stepping up of soil curves. So, they do not provide high precision input facility for the $\mathrm{Q}$ and $\mathrm{t}$ factors. So the PSI (Pile Structure Interaction) modifications cannot be done with more accuracy with the current version of the software.

Table 1. Obtained foundation capacity ratio

\begin{tabular}{ccc} 
Jacket & \multicolumn{2}{c}{ SPD19C } \\
\hline Type of pile & P1 & P2 \\
\hline Diameter & $152.4[\mathrm{~cm}]$ & $152.4[\mathrm{~cm}]$ \\
\hline Penetration Depth & $88.47[\mathrm{~m}]$ & $94.483[\mathrm{~m}]$ \\
\hline Required Capacity Ratio & 1.42 & 1.42 \\
\hline Actual Capacity & $45953.7[\mathrm{kN}]$ & $52651.6[\mathrm{kN}]$ \\
\hline Aged Capacity & $65438.1[\mathrm{kN}]$ & $74765.3[\mathrm{kN}]$ \\
\hline Obtained Capacity Ratio & 1.424 & 1.424
\end{tabular}

\section{Pushover Analysis}

The pushover analysis is conducted for the SPD19C jacket platform, using the actual and aged soil curves. This jacket exists in Persian Gulf (South Pars gas field Development, phase 19) and it is a four-legged platform, as shown in the Figure-1. The self-weight of the jacket platform, buoyancy, installed equipment and live load were applied on the platform in the first phase of the pushover analysis with load factor of 1.0. The second phase of the pushover analysis is performed by the environmental load on the platform with increasing the load factor until the platform collapsed. Pushover analysis is carried out separately for eight selected 
loading direction namely; $\mathrm{N}\left(0^{\circ}\right), \mathrm{NE}\left(45^{\circ}\right), \mathrm{E}\left(90^{\circ}\right)$, $\mathrm{SE}\left(135^{\circ}\right), \mathrm{S}\left(180^{\circ}\right), \mathrm{SW}\left(225^{\circ}\right), \mathrm{W}\left(270^{\circ}\right)$, and $\mathrm{NW}\left(315^{\circ}\right)$. The worst loading condition which causes the minimum RSR is the storm condition in $\mathrm{S}\left(180^{\circ}\right)$ direction. So this direction is selected to investigate the aging effect on the piles.

Reserve Strength Ratio (RSR) is a measure of structure's ability to withstand loads in excess of those determined from platform design and this can be obtained using the ultimate strength of the platform through pushover analysis. This reserve strength can be used to maintain the platform in service beyond their intended service life. Knowledge from this analysis can be used to determine the criticality of components within the structural system for prioritizing the inspection and repair schemes [12].

$$
R S R=\frac{B S_{\text {collapse }}}{B S_{\text {design }}}
$$

BS collapse $=$ the ultimate base shear capacity of the jacket prior to Collapse

$\mathrm{BS}$ design $=$ the design base shear loading on the jacket

The design base shear can be identified when the environmental load factor $=1.0$, while collapse base shear is the maximum base shear prior to collapse.

\section{Structural Modeling}

\subsection{Platform Data}

The jacket platform is four-legged drilling jacket with grouted steel piles for the purpose of supporting 2700 tones maximum operation weight located in the south pars gas field which is approximately located $210 \mathrm{~km}$ south east of port of Bushehr in a water depth of around $65.25 \mathrm{~m}$. The total height of the jacket is $93.85 \mathrm{~m}$ and the jacket footprint at sea floor is $32.16 \mathrm{~m} \times 23.04 \mathrm{~m}$ and leg spacing at working point is $24 \mathrm{~m} \mathrm{x} 13.716 \mathrm{~m}$. A perspective plot of the model is shown in Figure 1.

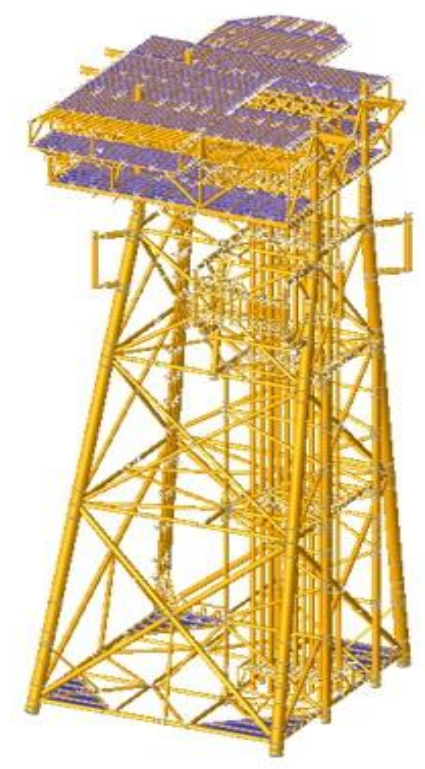

Figure 1. A perspective plot of the SACS 1
Three main components of the model are:

\subsubsection{Substructure:}

I. Jacket:

a) Jacket legs

b) Horizontal framings

c) Elevation bracings and diagonals

II. Appurtenances

The following appurtenances are explicitly modelled for the hydrodynamic actions.

a) One conductors 22 ', O.D $(55.88 \mathrm{~cm})$

b) One riser 18 " O.D $(45.72 \mathrm{~cm})$

c) One riser 6" O.D $(15.24 \mathrm{~cm})$

d) Two fire water pump caisson 18" O.D $(45.72 \mathrm{~cm})$

e) One fire water pump caisson 26" O.D $(66.04 \mathrm{~cm})$

f) Two J-tubes 8 " O.D $(20.32 \mathrm{~cm})$

\subsubsection{Foundation}

The foundation is modelled using uncoupled non-linear soil springs acting along the piles length. The loaddisplacement characteristics of these springs are defined by $\mathrm{p}-\mathrm{y}, \mathrm{q}-\mathrm{z}$ and $\mathrm{t}-\mathrm{z}$ curves based on geotechnical report. Based on pile makeup drawing the piles are modelled to penetration of $88.47 \mathrm{~m}$ and $94.48 \mathrm{~m}$ below mud-line. Pile outer diameter is 1524 $\mathrm{mm}$. The scour readings by survey report ranged from $400 \mathrm{~mm}$ to $900 \mathrm{~mm}$, so the final scour for modelling the platform was assumed equal to $1 \mathrm{~m}$ on all pile locations.

\subsubsection{Deck}

The topside has three deck levels and includes accommodations and different equipment. The model includes all the deck primary and secondary beams, truss chords, bracing and columns. Deck plates have been included as quadrilateral isotropic plate element for the in-plane stiffness of the deck.

\subsection{Material}

As per API RP 2SIM 2014 material specifications and properties of an existing structure are defined based on data from original design.

Table 2: Material properties [13]

\begin{tabular}{lcl} 
Density & $\rho=7850 \mathrm{~kg} / \mathrm{m} 3$ \\
\hline Young's modulus & & $\mathrm{E}=2.1 \mathrm{e} 11 \mathrm{~Pa}$ \\
\hline Poisson's ratio & & $v=0.3$ \\
\hline \multirow{2}{*}{ yield strength } & $t \leq 16$ & $235 \mathrm{MPa}$ \\
\cline { 2 - 3 } & $16<t \leq 40$ & $225 \mathrm{MPa}$
\end{tabular}

\subsection{Environmental Data \\ 4.3.1. Water Depth}

The platform is located in $65.25 \mathrm{~m}$ water depth. The design water levels and tidal range with 100 years return periods are summarized in table 3 . 
Table 3: Water depth and surface fluctuations (m)

\begin{tabular}{ll}
\hline Description & 100 Years \\
\hline Chart Datum Water Depth (To LAT) & 65.25 \\
\hline Mean Sea Level (MSL) & 1 \\
\hline MHHW & 1.6 \\
\hline HAT & 2 \\
\hline Storm Surge & 0.3 \\
\hline Possible Subsidence* & +0.5 \\
\hline Uncertainty Allowance & \pm 0.5 \\
\hline Maximum Water Depth & 68.05 \\
\hline Minimum Water Depth & 65.25 \\
\hline
\end{tabular}

The maximum water depth considered in the analysis is $68.05 \mathrm{~m}$ and the minimum water depth is $65.25 \mathrm{~m}$. Max. Water Depth $=$ Water Depth + HAT + Storm Surge + Subsidence

\subsubsection{Wind}

The wind loads are calculated based on the API RP 2A, using following-directional wind speeds for extreme storm conditions.

Table 4: 100-year return period wind speed $(\mathrm{m} / \mathrm{s})$

\begin{tabular}{lcccccccc}
\hline $\begin{array}{l}\text { Direction } \\
\text { from TN }\end{array}$ & NW & W & SW & S & SE & E & NE & N \\
\hline $\begin{array}{l}\text { wind } \\
\text { speed }\end{array}$ & 36 & 34.9 & 35.6 & 36.7 & 35.6 & 33 & 33.4 & 35.2 \\
\hline
\end{tabular}

Shape coefficients for perpendicular wind approach angles with respect to each projected area should be considered as follows (API RP2A-WSD-2014):

Beams

Sides of buildings

1.5

Cylindrical sections

Overall projected area of platform

\subsubsection{Wave and Current}

Directional waves are used for the pushover analysis. Wave height with associated period for extreme storm conditions are as follows:

Table 5: 100-years wave heights and associated wave periods

\begin{tabular}{lllllllll}
\hline Direction & NW & W & SW & S & SE & E & NE & N \\
\hline Wave & 10.8 & 8.8 & 9.7 & 12.2 & 10.8 & 8.8 & 10.2 & 11.6 \\
Height & $\mathrm{m}$ & $\mathrm{m}$ & $\mathrm{m}$ & $\mathrm{m}$ & $\mathrm{m}$ & $\mathrm{m}$ & $\mathrm{m}$ & $\mathrm{m}$ \\
\hline Wave & 10.4 & 9.6 & 10 & 11 & 10.4 & 9.5 & 10.2 & 10.8 \\
Period & $\mathrm{sec}$ & $\mathrm{sec}$ & $\mathrm{sec}$ & $\mathrm{sec}$ & $\mathrm{sec}$ & $\mathrm{sec}$ & $\mathrm{sec}$ & $\mathrm{sec}$ \\
\hline
\end{tabular}

The following currents are considered for the design of the platform.
Table 6: 100-years return period current profile $(\mathrm{m} / \mathrm{s})$

\begin{tabular}{lllllllll}
\hline Elevation & \multicolumn{7}{c}{ Direction } \\
\cline { 2 - 8 } & $\mathrm{NW}$ & $\mathrm{W}$ & $\mathrm{SW}$ & $\mathrm{S}$ & $\mathrm{SE}$ & $\mathrm{E}$ & $\mathrm{NE}$ & $\mathrm{N}$ \\
\hline Surface $(\mathrm{m} / \mathrm{s})$ & 1.28 & 1.28 & 1.28 & 1.28 & 1.28 & 1.28 & 1.28 & 1.28 \\
\hline $\begin{array}{l}50 \% \text { Water } \\
\text { Depth }(\mathrm{m} / \mathrm{s})\end{array}$ & 1.28 & 1.28 & 1.28 & 1.28 & 1.28 & 1.28 & 1.28 & 1.28 \\
\hline $\begin{array}{l}1.0 \mathrm{~m} \text { above } \\
\text { Seabed (m/s) }\end{array}$ & 0.78 & 0.78 & 0.78 & 0.78 & 0.78 & 0.78 & 0.78 & 0.78 \\
\hline $\begin{array}{l}0.5 \mathrm{~m} \text { above } \\
\text { Seabed }(\mathrm{m} / \mathrm{s})\end{array}$ & 0.71 & 0.71 & 0.71 & 0.71 & 0.71 & 0.71 & 0.71 & 0.71 \\
\hline
\end{tabular}

\subsubsection{Hydrodynamic Coefficients}

Basic drag and inertia coefficients used to evaluate wave forces on cylindrical members are as follows:

Table 7: Hydrodynamic coefficients for calculating the storm wave loads

\begin{tabular}{lll}
\hline Surface Conditions & $\mathrm{Cm}$ & $\mathrm{Cd}$ \\
\hline Clean Steel & 1.6 & 0.65 \\
\hline Marine Growth Fouled & 1.2 & 1.1 \\
\hline
\end{tabular}

The wave kinematics factor should be taken as 0.9 as per API RP-2A. The current blockage factors for the 4 legged structures are as API RP-2A.
- End-on
0.70
- Diagonal
0.85
- Broadside
0.80

\subsubsection{Marine Growth Profile}

Marine growth can lead to the rise in the increase of the weight, hydrodynamic added mass and hydrodynamic actions, and may influence hydrodynamic instability. For typical design situations, global hydrodynamic action on a structure can be calculated using Morison's equation, with the values of the hydrodynamic coefficients for unshielded circular cylinders [10]. Presents the marine growth thickness measured by underwater survey. The specific weight of marine growth in air considered equal to $1.4 \mathrm{kN} / \mathrm{m}^{3}$.

Table 9: Marine growth thickness [14]

\begin{tabular}{|c|c|c|c|c|c|c|c|}
\hline $\begin{array}{l}\text { Top } \\
\text { elevation }\end{array}$ & $\begin{array}{l}0.00 \\
\mathrm{~m}\end{array}$ & $\begin{array}{l}8.1 \\
\mathrm{~m}\end{array}$ & $\begin{array}{l}18.1 \\
\mathrm{~m}\end{array}$ & $\begin{array}{l}28.1 \\
\mathrm{~m}\end{array}$ & $\begin{array}{l}38.1 \\
\mathrm{~m}\end{array}$ & $\begin{array}{l}48.1 \\
\mathrm{~m}\end{array}$ & $\begin{array}{l}58.1 \\
\mathrm{~m}\end{array}$ \\
\hline $\begin{array}{l}\text { Bottom } \\
\text { elevation }\end{array}$ & $\begin{array}{l}8.1 \\
\mathrm{~m}\end{array}$ & $\begin{array}{l}18.1 \\
\mathrm{~m}\end{array}$ & $\begin{array}{l}28.1 \\
\mathrm{~m}\end{array}$ & $\begin{array}{l}38.1 \\
\mathrm{~m}\end{array}$ & $\begin{array}{l}48.1 \\
\mathrm{~m}\end{array}$ & $\begin{array}{l}58.1 \\
\mathrm{~m}\end{array}$ & $\begin{array}{l}66.1 \\
\mathrm{~m}\end{array}$ \\
\hline Thickness & $\begin{array}{l}5.0 \\
\mathrm{~mm}\end{array}$ & $\begin{array}{l}5.5 \\
\mathrm{~mm}\end{array}$ & $\begin{array}{l}6.0 \\
\mathrm{~mm}\end{array}$ & $\begin{array}{l}6.5 \\
\mathrm{~mm}\end{array}$ & $\begin{array}{l}7.0 \\
\mathrm{~mm}\end{array}$ & $\begin{array}{l}7.5 \\
\mathrm{~mm}\end{array}$ & $\begin{array}{l}7.5 \\
\mathrm{~mm}\end{array}$ \\
\hline
\end{tabular}

\subsubsection{Soil Condition}

The analysis includes the effect of the non-linear soil stiffness through the soil-structure interaction software named SACS PSI. The soil model is subdivided into seven layers. The design soil parameters are presented in Table 10. 
Table 10: Parameter values for 19c platform existing pile capacity

\begin{tabular}{|c|c|c|c|c|c|c|c|}
\hline $\begin{array}{l}\text { Layer } \\
\text { num. }\end{array}$ & 1 & 2 & 3 & 4 & 5 & 6 & 7 \\
\hline Depth & $\begin{array}{l}0- \\
16 \\
\mathrm{~m}\end{array}$ & $\begin{array}{c}16- \\
17.8 \\
\mathrm{~m}\end{array}$ & $\begin{array}{c}17.8 \\
-32 \\
m\end{array}$ & $\begin{array}{c}32- \\
49 \\
\mathrm{~m}\end{array}$ & $\begin{array}{c}49- \\
60 \\
\mathrm{~m}\end{array}$ & $\begin{array}{c}60- \\
71.3 \\
\mathrm{~m}\end{array}$ & $\begin{array}{c}71.3- \\
100.3 \\
\mathrm{~m}\end{array}$ \\
\hline $\begin{array}{l}\text { Soil } \\
\text { type }\end{array}$ & $\mathrm{T}-1$ & T-2 & $\mathrm{T}-1$ & T-2 & $\mathrm{T}-1$ & $\mathrm{~T}-2$ & $\mathrm{~T}-1$ \\
\hline$\delta$ & - & $20^{\circ}$ & - & $23^{\circ}$ & - & $20^{\circ}$ & - \\
\hline top & 5 & - & 55 & - & 110 & - & 150 \\
\hline bot & 50 & - & 85 & - & 180 & - & 220 \\
\hline $\begin{array}{l}\text { Sub. unit } \\
\text { wt. }\end{array}$ & $\begin{array}{l}8 \\
\mathrm{kN} / \\
\mathrm{m}^{3} \\
\end{array}$ & $\begin{array}{l}9 \\
\mathrm{kN} / \\
\mathrm{m}^{3} \\
\end{array}$ & $\begin{array}{l}8 \\
\mathrm{kN} / \\
\mathrm{m}^{3} \\
\end{array}$ & $\begin{array}{l}9 \\
\mathrm{kN} / \\
\mathrm{m}^{3} \\
\end{array}$ & $\begin{array}{l}9 \\
\mathrm{kN} / \\
\mathrm{m}^{3} \\
\end{array}$ & $\begin{array}{l}9 \\
\mathrm{kN} / \\
\mathrm{m}^{3}\end{array}$ & $\begin{array}{l}9 \\
\mathrm{kN} / \\
\mathrm{m}^{3} \\
\end{array}$ \\
\hline $\mathrm{Nq}$ & - & 12 & - & 15.8 & - & 12 & - \\
\hline $\mathrm{f}_{\mathrm{lim}}$ & - & $\begin{array}{l}15 \\
\mathrm{kPa}\end{array}$ & - & $\begin{array}{l}15 \\
\mathrm{kPa}\end{array}$ & - & $\begin{array}{l}15 \\
\mathrm{kPa}\end{array}$ & - \\
\hline qlim & - & $\begin{array}{l}3 \\
\mathrm{MPa} \\
\end{array}$ & - & $\begin{array}{l}5 \\
\mathrm{MPa} \\
\end{array}$ & - & $\begin{array}{l}3 \\
\mathrm{MPa} \\
\end{array}$ & - \\
\hline
\end{tabular}

Where:

$$
\begin{array}{ll}
\mathrm{T}-1 & =\text { Clay } \\
\mathrm{T}-2 & =\text { calcarenite } \\
\delta & =\text { soil-pile friction angle } \\
\mathrm{Cu} & =\text { undrained shear strength } \\
\mathrm{Nq} & =\text { bearing capacity factor } \\
\mathrm{f}_{\mathrm{lim}} & =\text { limit unit skin friction }(\mathrm{kPa}) \\
\mathrm{q}_{\mathrm{lim}} & =\text { limit unit end bearing pressure }(\mathrm{MPa})
\end{array}
$$

\section{Results and discussion}

Pushover analysis results in with and without incorporating the aging effects of piles in clayey soil in $180^{\circ}$ direction which are given in table 11. As mentioned before, this direction causes the minimum RSR (Reserve Strength Ratio) for the platform so it is the critical condition. The improved RSR for the aged case proves the hypothesis of aging effect. The improvement of $10 \%$ is observed in pushover analysis results.

Table 11. Pushover analysis results of SPD19C platform

\begin{tabular}{lll} 
Pushover direction & $\mathrm{S}\left(180^{\circ}\right)$ \\
\hline Design Base Shear & Base Shear & $2439.26 \mathrm{kN}$ \\
\cline { 2 - 3 } Actual & RSR & 2.0 \\
\hline \multirow{2}{*}{ Aged } & Base Shear & $26838.37 \mathrm{kN}$ \\
\cline { 2 - 3 } & RSR & 2.2 \\
\hline \multirow{2}{*}{ Improvement } & & $10.0 \%$
\end{tabular}

\section{Conclusion}

The increase in RSR (Reserve Strength Ratio) proves that an aged platform contains higher capacity than the designed capacity. However, the reduction in the RSR does not convey the exact opposite sense. Even when the structure has collapsed, the foundation has more capacity which should be utilized. Also for most of the cases where the RSR was improved, the foundation capacity was not completely used. Therefore, the performance of the jacket platforms can be further improved with careful planning and execution of the maintenance and strengthening of the critical member in the jacket which contributed to the structure collapse.

The certain conclusions of this research are listed below:

- Disagreement between the simulation and actual cases in terms of their collapse strength is due to the aging effects of piles.

- The incorporation of aging effect of pile into the pushover analysis of offshore jacket platforms can produce improvements in the RSR (Reserve Strength Ratio) of the structure. In this special research, this effect resulted in 10 percent improvement in the RSR.

- The aged foundation capacity is not utilized in the most of the rehabilitation scenarios but this can be averted if a target based maintenance and strengthening of the jacket is performed.

\section{References}

1- Nichols, N. W., Goh, T. K. and Bahar, H., (2006), Managing Structural Integrity for Aging Platform, in SPE Asia Pacific Oil and Gas Conference and Exhibition, Adelaide,Australia. [DOI: 10.2118/101000-MS]

2- George, J. M., Wahab, M. M. A., and Kurian, V. J., (2016), Changes in The Pushover Analysis of Offshore Jacket Platforms Due to The Incorporation of The Aging Effect of Piles, ARPN Journal of Engineering and Applied Science, vol. 11.

3- Gilbert, R. B., Chen, J. -Y., Materek, B., Puskar, F., Carpenter, J. and Young, A., (2010), Comparison of Observed and Predicted Performance for Jacket Pile Foundations in Hurricanes, in Offshore Technology, Houston, Texas, USA.

4- George, J. M., Wahab, M. M. A. and Kurian, V. J., (2015), Estimation of Aging Effects of Piles in Malaysian Offshore Locations, Journal of Engineering Science and Technology, (In publication).

5- El-Reedy, M. A., (2014). Marine Structural Design Calculations, United Kingdom: Butterworth Heinemann.

6- Clarke, J., (1993), Large-Scale Pile Tests in Clay, London: Thomas Telford.

7- Bogard, J. D. and Matlock, H., (1990), Applications of model pile tests to axial pile design, in Proceedings of the 22nd Annual Offshore Technology Conference, Houston Texas. [DOI: 10.4043/6376-MS]

8- komurka, V. E., Wagner, A. B. and Edil, T. B., (2003), Estimating soil/pile set-up, The Wisconsin Highway Research Program (WHRP).

9- Lied, E. K. W., (2006), A Study of Time Effects on Pile Capacity NGI Report, Norwegian Geotechnical Institute, Norway.

10- Skov, R. and Denver, H., (1988), Piles TimeDependence of Bearing Capacity of Piles, in Proceedings of the 3rd international conference on the application of stress-wave theory to piles, Ottawa, 


\section{Canada.}

11- Bentley Systems, (2010). SACS Software Manual, From Engineering Dynamics Inc.

12- Narayanan, S. P. and Kabir, M., (2009), Structural Integrity Management for Fixed Offshore Platform in Malaysia, Malaysia: World Academy of Science,
Engineering and Technology. [DOI: 1999.3/6666] 13- DIN, German Institute for Standardization, German: Deutsches Institut fur Normung. 14- API, (2013), Structural Integrity Management of Fixed Offshore Structures, American Petrolume Institute. [DOI: 10.4043/20675-MS] 